\title{
Acquisition of microbiota according to the type of birth: an integrative review
}

\author{
Gabriela Diniz Pinto Coelho ${ }^{1}$ \\ (Dhttps://orcid.org/0000-0002-0044-3579 \\ Lilian Fernandes Arial Ayres ${ }^{1}$ \\ (D)https://orcid.org/0000-0003-3809-2660 \\ Daniela Sezilio Barreto ${ }^{1}$ \\ (1) https://orcid.org/0000-0003-4588-0948 \\ Bruno David Henriques ${ }^{1}$ \\ (1) https://orcid.org/0000-0002-6844-6661 \\ Mara Rúbia Maciel Cardoso Prado ${ }^{1}$ \\ (D)https://orcid.org/0000-0001-6314-0009 \\ Camila Mendes Dos Passos ${ }^{1}$ \\ (1Dhttps://orcid.org/0000-0003-1230-2500
}

Universidade Federal de Viçosa, Departamento de Medicina e Enfermagem, Viçosa, MG, Brasil.
Objective: to analyze scientific evidence regarding the relationship between the type of birth and the microbiota acquired by newborns. Method: this integrative review addresses the role of the type of delivery on newborns' microbial colonization. A search was conducted in the Medical Literature Analysis and Retrieval System Online/PubMed and Virtual Health Library databases using the descriptors provided by Medical Subject Headings (MeSH) and Health Science Descriptors (DeCS). Results: infants born vaginally presented a greater concentration of Bacteroides, Bifidobacteria, and Lactobacillus in the first days of life and more significant microbial variability in the following weeks. The microbiome of infants born via C-section is similar to the maternal skin and the hospital setting and less diverse, mainly composed of Staphylococcus, Streptococcus, and Clostridium. Conclusion: the maternal vaginal microbiota provides newborns with a greater variety of colonizing microorganisms responsible for boosting and preparing the immune system. Vaginal birth is the ideal birth route, and C-sections should only be performed when there are medical indications.

Descriptors: Microbiota; Obstetric Delivery; Cesarean Section; Parturition; Immune System; Newborn Infant.

\section{How to cite this article}

Coelho GDP, Ayres LFA, Barreto DS, Henriques BD, Prado MRMC, Passos CM. Acquisition of microbiota according to the type of birth: an integrative review. Rev. Latino-Am. Enfermagem. 2021;29:e3446. [Access $\underset{\text { month day }}{-} \underset{\text { year }}{1}$; Available in: DOI: http://dx.doi.org/10.1590/1518-8345.4466.3446. 


\section{Introduction}

The Brazilian obstetrical context is of concern and considered a public health problem due to various factors, including the C-section epidemic. According to the World Health Organization (WHO), the rate of C-sections should not exceed $15 \%{ }^{(1)}$; however, approximately $90 \%$ of the deliveries in the supplementary health system are C-sections, while in the Unified Health System (SUS), this rate reaches $45 \%{ }^{(2)}$.

There is a higher risk of bleeding in the intraand post-operative of C-sections ${ }^{(3-5)}$, in addition to infections in the surgical site ${ }^{(6-7)}$, puerperal sepsis, deep venous thrombosis, endotoxin shock ${ }^{(8)}$, and lengthier hospitalizations due to slower recovery ${ }^{(6)}$.

The route of birth delivery may also influence a newborn's health. Children born via C-section are at increased risk of developing asthma, systemic connective tissue disorders, juvenile arthritis, inflammatory bowel disease, immune deficiencies, and leukemia(9). Part of these diseases is believed to be related to the maturation of the neonatal immune system ${ }^{(10-11)}$

Studies suggest that the immune system of a newborn is widely stimulated when first exposed to microorganisms during neonatal life ${ }^{(11)}$, while the type of delivery shapes an infant's microbial communities, which consequently play a role in his/her immune system maturation ${ }^{(12)}$.

Therefore, we propose that the route of birth delivery influences the colonization of microorganisms in newborns. Nonetheless, studies seldom address the mechanisms involved in this adaptation according to the type of birth. This study's findings are expected to support the choice of the type of birth, decreasing unnecessary C-sections without a medical indication. Fetal morbidity and mortality caused by $\mathrm{C}$-sections and inappropriate adaptation of the neonatal immunological system are also expected to decrease.

Therefore, this study's objective was to analyze scientific evidence concerning the relationship between the route of birth delivery and the newborns' acquisition of microbiota.

\section{Method}

This is an integrative review, which can be defined as a method capable of synthesizing scientific knowledge regarding a given problem ${ }^{(13)}$. It also allows researchers to monitor a topic's development over time and formulate new theories and generate knowledge ${ }^{(14)}$. It allows incorporating studies with the most diverse methodological designs, and for this reason, is considered a complex tool(14).

This study strictly followed the proposed stages(15), namely: 1st) establishment of the topic and guiding question; 2nd) establishment of inclusion and exclusion criteria; 3rd) identification of studies; 4th) categorization of studies; 5th) analysis and interpretation of results; 6th) synthesis of knowledge and presentation of results.

PICO, which stands for Patient, Intervention, Comparison, and Outcomes, was the strategy used to establish the guiding question. These four components are essential to establish the guiding question and, consequently, seek scientific evidence(16).

Therefore, the topic chosen was the acquisition of microbiota among newborns according to the route of birth delivery. The guiding question was: What is the production of knowledge concerning the association between the acquisition of microbiota among newborns and the route of birth delivery? The first element of the strategy $(P)$ refers to newborns; the second (I) to C-section; the third refers to vaginal delivery $(\mathrm{C})$; and the fourth element $(\mathrm{O})$ refers to newborns' acquired microbiota.

Inclusion criteria were: papers published in Portuguese, English, or Spanish; answering the guiding question; with up to ten years since publication. Exclusion criteria were letters, editorials, experts' opinions, reviews, and studies addressing premature infants, or not comparing the route of birth nor addressing newborns.

An advanced search was performed in the following electronic databases to select the studies for this review: Medical Literature Analysis and Retrieval System Online (MEDLINE) (via PubMed), Latin American and Caribbean Health Sciences Literature (LILACS), and Índice Bibliográfico Español en Ciencias de la Salud (IBECS) (via Virtual Health Library-VHL), on August 10th, 2020. The following descriptors were used in the search strategy: (("MICROBIOTA") AND (("DELIVERY, OBSTETRIC") OR ("CESAREAN SECTION") OR ("PARTURITION")) NOT ("MILK, HUMAN")) in the PubMed and (tw:(MICROBIOTA)) AND (tw:(HUMANS)) AND (tw:(PARTURITION OR CESAREAN SECTION OR DELIVERY, OBSTETRIC)) AND NOT (tw:(HUMAN, MILK)) in the VHL.

The equivalent descriptors in Portuguese and Spanish were used in the VHL to identify Latin American studies, namely: (tw:(MICROBIOTA)) AND (tw:(HUMANOS)) AND (tw:(PARTO OR CESÁREA OR PARTO OBSTÉTRICO)) AND NOT (tw: (LEITE HUMANO OR LECHE HUMANA)).

The descriptors used in the PubMed were selected from the Medical Subject Headings (MeSH terms), used for the efficient indexing of publication in the topic ${ }^{(17)}$. The descriptors from the Health Science Descriptors (DeCS) were used in the search in the VHL. 
The Preferred Reporting Items for Systematic Reviews and Meta-Analyses - PRISMA was adapted to guide this review's report ${ }^{(18)}$. After gathering the studies identified in the two electronic databases, those that appeared more than once were excluded after comparing titles, authors, year of publication, and country of origin. Duplicated studies were kept in the database with the largest number of references (PubMed). Two of the authors independently screened the titles and abstracts according to the eligibility criteria.

Afterward, the full texts of the studies selected were considered in a new screening process. The researchers independently examined all the publications to choose the studies that met the inclusion criteria previously mentioned. Conflicts were resolved in a consensual meeting.

The studies were then analyzed using an instrument to collect data(19) addressing the study's title, journal, authors, country of origin, language, year of publication, hosting institution, type of scientific journal, methodological characteristics, and an assessment of the studies' methodological rigor. Data were entered in the Excel program.
The studies were also analyzed according to the level of evidence. In this study, the level of evidence was organized into seven levels: Level I - systematic review or meta-analysis of randomized controlled clinical trials; Level II - evidence obtained from at least one well-designed randomized controlled clinical trial; Level III - well-designed controlled trial without randomization; Level IV - evidence from well-designed case-control or cohort studies; Level V - systematic reviews of descriptive and qualitative studies; Level VI - evidence form a single descriptive or qualitative study; Level VII - evidence from the opinion of authorities and/or reports of expert committees $^{(20)}$.

The studies were tabulated and rigorously analyzed, interpreted, and synthesized. Two thematic categories were chosen according to the topics addressed in the studies to interpret the results.

\section{Results}

This study's sample was composed of 25 studies. The entire process of searching, excluding, and selecting studies is described in detail in a flowchart (Figure 1).

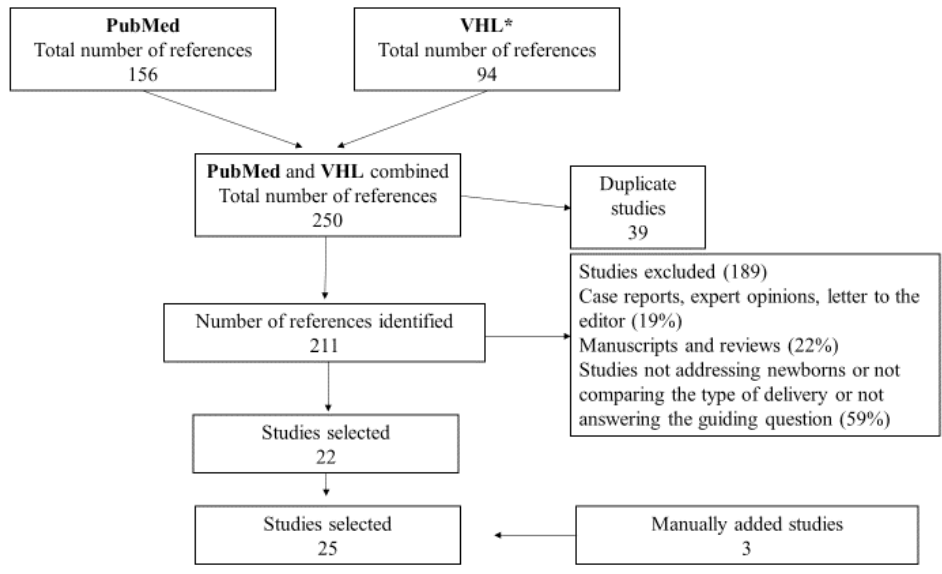

*VHL $=$ Virtual Health Library

Figure 1 - Studies selection process: adapted from the PRISMA flowchart ${ }^{(18)}$

The year of publication among the studies selected ranged from 2010 and 2019: 32\% of the studies were published in 2016 , followed by $12 \%$ of the publications published in 2018, 2017, and 2015. Regarding the country of origin, the United States presented the highest number of studies (20\%), followed by Sweden and China, with $16 \%$ each. All the papers were written in English, and the periodical with the highest number of publications was PloS One with three papers. Nature Medicine, Nat Commun, EBioMedicine, Journal of Allergy and Clinical Immunology, Journal of Pediatric Gastroenterology and
Nutrition, and Scientific Reports published two papers each.

Analysis of the studies revealed similar results and discussions. Hence, two analytical categories emerged from the studies' analysis: microbiota and immune system and route of birth delivery and neonatal microbiota. Both are presented in the discussion section.

Figure 2 presents a synthesis of the knowledge presented by the studies with information concerning the authors, study designs, level of evidence, and main results. 


\begin{tabular}{|c|c|c|c|}
\hline Authors & Year & $\begin{array}{c}\text { Study design/Level of } \\
\text { evidence }\end{array}$ & Main Results \\
\hline Liu, et al.(21) & 2019 & $\begin{array}{l}\text { Well-designed } \\
\text { controlled trial without } \\
\text { randomization/III }\end{array}$ & $\begin{array}{l}\text { Only samples of the amniotic fluid showed significant differences }(p<0.001) \text { according } \\
\text { to the type of birth. While meconium, placenta, and fetal membrane samples showed no } \\
\text { significant differences between newborns born vaginally or via C-section. Vaginal delivery: } \\
\text { Lactobacillus and Gardnerella; C-section: Thermus and Tepidiphilus. }\end{array}$ \\
\hline $\begin{array}{l}\text { Reyman, et } \\
\text { al. }{ }^{(22)}\end{array}$ & 2019 & Cohort/IV & $\begin{array}{l}\text { Up to two months of life, the microbial community of children born vaginally was more stable } \\
\text { than that of children born via C-section. Abundant Bifidobacteria is associated with the } \\
\text { type of delivery, age, and whether the child is breastfed. Breastfeeding, however, does not } \\
\text { make up for the lack of Bifidobacteria among children born via C-section. Vaginal delivery: } \\
\text { Bifidobacteria and Escherichia; C-section: Klebsiella and Enterococcus. }\end{array}$ \\
\hline $\mathrm{Li}$, et al. ${ }^{(23)}$ & 2018 & $\begin{array}{l}\text { Well-designed } \\
\text { controlled trial without } \\
\text { randomization/III }\end{array}$ & $\begin{array}{l}\text { The vaginal delivery group has significantly more Bifidobacteria and Akkermansiaceae, } \\
\text { showing the beneficial aspect of natural birth. Two common pathogenic bacteria, Providencia } \\
\text { and Gardnerella, were also found in some of the infants in this group, which may be } \\
\text { explained by the presence of mothers with vaginal infections that had not been manifested. }\end{array}$ \\
\hline
\end{tabular}

Shi, et al. ${ }^{(24)} 2018$ Cohort/IV

Wampach, et al. ${ }^{(25)}$

Cohort/IV

Well-designed

Brazier, et al. ${ }^{(26)} 2017 \quad$ controlled trial without randomization/III

Chu, et al. ${ }^{(27)} \quad 2017 \quad$ Cohort/IV

Hill, et al. (28)

Cohort/IV

Bokulich, et

al. ${ }^{(29)}$

Well-designed controlled trial without randomization/III

Bosch, et al. ${ }^{(30)}$

Cohort/IV

Brumbaugh, et al. ${ }^{(31)}$

Well-designed controlled trial without randomization/III

Well-designed controlled trial without randomization/III
The microbiome of children born vaginally is a little more diverse than that of children born via C-section. Vaginal delivery: Actinobacteria, Gammaproteobacteria, and Betaproteobacteria; C-section: Deinococcus, Alphaproteobacteria, and Bacilli.

Type of delivery was considered the dominant driver of the colonization of the neonata gut microbiome. Vaginal delivery influences the transference of functional characteristics involved in microbial pathways, such as the biosynthesis of lipopolysaccharides that are important in developing a newborn's immune system.

The type of delivery influenced the fecal microbial composition. Vaginal delivery: Bacteroides and Collinsella; C-section: Klebsiella and Sarcina.

The neonatal microbial community structure at the time of delivery did not show significant differences according to the body's site. Vaginal delivery: Lactobacillus; C-section: Propionibacterium and Streptococcus. The microbiota of newborns born vaginally tended to be similar to their mothers' vagina, while infants born via elective C-sections were mainly populated by the microbiota found on their mothers' skin.

The structure of an infant's gut microbiota is affected by the type of delivery. Vaginal birth: Bifidobacteria, Bacteroides; C-section: Clostridium. A large diversity of individual population structures was found within each group, showing the heterogeneous gut microbiota composition of developing infants.

The children born via C-section showed a significantly greater phylogenetic diversity $(p<0.05)$. However, these significantly decreased during the first month after birth while these children subsequently presented a lower diversity and less richness up to 2 years of age.

Children born vaginally tend to change profiles dominated by Moraxella and Corynebacterium/Dolosigranulum in an earlier stage than children born via C-section, who remain longer in a profile dominated by $\mathrm{S}$. aureus.

Significant differences were found at the phylum level and bacterial abundance at a gender level, according to the type of delivery for all the infants' samples. Vaginal delivery: Oropharynx: Firmicutes (Lactobacillus). Fecal samples: Bacteroidetes; C-section: Oropharynx: Actinobacteria (Propionibacterium) and Proteobacteria. Fecal samples: Proteobacteria. Disturbances in colonization and succession within the human gut in early life may influence the risk of long-term illnesses.

Regardless of the body site, the microbiome of infants born vaginally or via C-section were more similar to their mothers' vaginal microbiome, when exposed to vaginal fluid, than that of infants born via C-section but not exposed.

C-section was associated with infection and inflammation of the mucosa. The effect of elective $\mathrm{C}$-sections was more significant for asthma than emergency $\mathrm{C}$-sections. Estimates of respiratory tract disease did not change after adjusting for neonatal respiratory morbidity. 


\begin{tabular}{|c|c|c|c|}
\hline Authors & Year & $\begin{array}{l}\text { Study design/Level of } \\
\text { evidence }\end{array}$ & Main Results \\
\hline Martin, et al. ${ }^{(33)}$ & 2016 & Cross-sectional/VI & $\begin{array}{l}\text { The type of delivery was one of the factors that strongly impacted the initial composition of } \\
\text { newborns' microbiota. The infants born vaginally had significantly higher bacterial counts in } \\
\text { the meconium than those born by C-section. Infants born via C-section had late colonization } \\
\text { of various groups of bacterial species. Vaginal birth: Bifidobacterium, Bacteroides fragilis, } \\
\text { B. ovatus, B. vulgatus, B. uniformis, B. caccae, and B. longum subsp. Longum; C-section: } \\
\text { Enterococcus and C. perfringens. }\end{array}$ \\
\hline Shilts, et al. ${ }^{(34)}$ & 2016 & Cohort/IV & $\begin{array}{l}\text { The taxonomic profile of the nasal microbiome of infants born vaginally was closer to the } \\
\text { nasal microbiome previously found in adults, compared to infants born via C-section. This } \\
\text { finding supports the hypothesis that the nasal microbiome of infants born vaginally may } \\
\text { represent an environment successfully colonized by stable commensal microbiota. Vaginal } \\
\text { delivery: Actinobacteria (Corynebacterium); C-section: Firmicutes (Staphylococcus). }\end{array}$ \\
\hline $\begin{array}{l}\text { Stokholm, et } \\
\text { al. }^{(35)}\end{array}$ & 2016 & Cohort/IV & $\begin{array}{l}\text { Type of birth was associated with different gut bacterial colonization patterns in early } \\
\text { childhood, which normalizes during the first year of life. Elective and emergency C-sections } \\
\text { were associated with distinctly different colonization patterns. Vaginal birth: E. coli; } \\
\text { C-section: Citrobacter freundii, Enterobacter cloacae, Enterococcus faecalis, Klebsiella } \\
\text { oxytoca, Klebsiella pneumoniae, and Staphylococcus aureus.l }\end{array}$ \\
\hline $\begin{array}{l}\text { Bäckhed, et } \\
\text { al. }^{(36)}\end{array}$ & 2015 & Cohort/IV & $\begin{array}{l}\text { The route of birth strongly affected the microbiome species in neonates. Vaginal } \\
\text { birth: Bacteroides, Bifidobacterium, Parabacteroides, Escherichia/Shigella; C-section: } \\
\text { Enterobacter sp., Haemophilus sp., Staphylococcus sp., Streptococcus australis, and } \\
\text { Veillonella sp. }\end{array}$ \\
\hline Dogra, et al. ${ }^{(37)}$ & 2015 & Cohort/IV & $\begin{array}{l}\text { The bacteria colonizing newborns' bodies promote a long-lasting effect in the immune } \\
\text { system or on the gut barrier function, driven by the type of delivery. Vaginal birth: } \\
\text { Bifidobacterium and Collinsella. C-section: Klebsiella, Enterobacteriaceae, and } \\
\text { Streptococcus. A lower or later colonization by Bifidobacteria was found among infants born } \\
\text { via C-section; Bifidobacteria are considered to be ideal in a newborn's organism. }\end{array}$ \\
\hline Dong, et al. ${ }^{(38)}$ & 2015 & Cross-sectional/VI & $\begin{array}{l}\text { The route of the birth delivery had a more significant impact on the gut microbiota structure } \\
\text { than on its diversity during the first } 4 \text { days of life. Vaginal birth: DAY 2: E coli and Bacteroides } \\
s p \text {. DAY 4: Bifidobacterium } s p \text { and Bacteroides sp; C-section: DAY 2: Staphylococcus sp, } \\
\text { Clostridium sp, and Enterobacter sp. DAY 4: Clostridium } s p \text { and Streptococcus } s p \text {. }\end{array}$ \\
\hline Hesla, et al..$^{(39)}$ & 2014 & Cohort/IV & $\begin{array}{l}\text { Vaginal birth: Bacteroides. C-section: Enterobacteriaceae, Clostridium, Haemophilus, } \\
\text { Veillonella. }\end{array}$ \\
\hline $\begin{array}{l}\text { Jakobsson, et } \\
\text { al. }{ }^{(40)}\end{array}$ & 2014 & $\begin{array}{l}\text { Well-designed } \\
\text { controlled trial without } \\
\text { randomization/III }\end{array}$ & $\begin{array}{l}\text { A lower microbial diversity was found among infants born via C-section and lower circulating } \\
\text { levels of the Th1-type chemokines, CXCL10 and CXCL11. }\end{array}$ \\
\hline Makino, et al. ${ }^{(41)}$ & 2013 & $\begin{array}{l}\text { Well-designed } \\
\text { controlled trial without } \\
\text { randomization/III }\end{array}$ & $\begin{array}{l}\text { The number of Bifidobacteria was significantly lower among infants born through C-section } \\
\text { than among infants born vaginally up to } 7 \text { days of age. Bifidobacteria gut colonization is } \\
\text { considered to begin more rapidly among infants born vaginally than among infants born } \\
\text { through C-sections. }\end{array}$ \\
\hline Pandey, et al. ${ }^{(42)}$ & 2012 & $\begin{array}{l}\text { Well-designed } \\
\text { controlled trial without } \\
\text { randomization/III }\end{array}$ & $\begin{array}{l}\text { The initial colonization and acquisition of gut microbiota may strongly influence the status of } \\
\text { cellular and humoral elements of the immune system of the gut mucosa during a newborn's } \\
\text { life. Vaginal delivery: Staphylococcus haemolyticus; Acinetobacter sp., Bifidobacterium } \\
\text { sp. C-section: Roseomonas pecuniae, Paracoccus sp., Enterococcus sp., Streptococcus } \\
\text { vestibularis, Chryseomicrobium imtechense, and Staphylococcus sp., Clostridium difficile, } \\
\text { Citrobacter sp. and Escherichia coli. }\end{array}$ \\
\hline $\begin{array}{l}\text { Biasucci, et } \\
\text { al. }{ }^{(43)}\end{array}$ & 2010 & $\begin{array}{l}\text { Well-designed } \\
\text { controlled trial without } \\
\text { randomization/III }\end{array}$ & $\begin{array}{l}\text { The study reports Bifidobacterium's presence in } 13 \text { of the } 23 \text { (56.5\%) samples from infants } \\
\text { born vaginally, but not in the samples obtained from infants born via C-section. }\end{array}$ \\
\hline $\begin{array}{l}\text { Dominguez- } \\
\text { Bello, et al. }{ }^{(44)}\end{array}$ & 2010 & $\begin{array}{l}\text { Randomized Clinical } \\
\text { Trial// }\end{array}$ & $\begin{array}{l}\text { The newborns harbored bacterial communities that were essentially undifferentiated on the } \\
\text { skin, nasal, nasopharynx, and gut habitats, regardless of the type of birth delivery. These } \\
\text { results show that human microbiota is homogeneously distributed throughout the body in the } \\
\text { early stage of community development. }\end{array}$ \\
\hline
\end{tabular}

Figure 2 - Synthesis of the knowledge presented by the studies selected 


\section{Discussion}

A rise in the C-section rates, diet changes, the indiscriminate use of antibiotics, and antimicrobial agents have altered the natural microbial composition of the human body. These may disturb the balance of commensal organisms and alter their metabolic network, favoring the growth of potentially pathogenic constituents, negatively reflecting on the population's health(23,45-46).

Therefore, it is essential to understand the importance of the microbiota for the immune system and its relationship with the route of birth delivery and a newborn's microbiota composition.

Studies show that microbiota is a crucial and active inducer of regulatory responses of the immune system $^{(11,47)}$. It is capable of inducing Regulatory $T$ cells (TReg) and macrophages to act against pathogenic antigens(48). Dysbiosis may prolong immunological immaturity and, consequently, increase the risk of autoimmune disorders ${ }^{(11,34,40,49-54)}$.

The neonatal period is considered a critical window in the development of the immunological system. Appropriate microbial stimulation is essential for the appropriate maturation of TReg cells response ${ }^{(55)}$. Shortchain fatty acids, a by-product of bacterial fermentation, are known for modulating $T$ cells' regulatory homeostasis (TReg) ${ }^{(56)}$. These are responsible for immunomodulatory or immunosuppressive responses; that is, they play a role in the body's immune tolerance, controlling inflammatory responses ${ }^{(57)}$. Dysregulation of these cells is directly linked to the development of allergic problems and autoimmune diseases ${ }^{(42,48)}$.

Additionally, the human organism's microbiota limits the colonization of pathogens based on a competition for metabolites, a process known as "colonization resistance"(57-58). The colonizing microbiota establishes a homeostatic relationship with the host, in which the colonization microorganisms benefit from the nutrient-rich environment, ensuring their survival and providing their hosts with a greater ability to absorb nutrients from food, establishing networks and biofilms capable of protecting the organism from pathogenic antigens, among other benefits ${ }^{(45,48)}$.

Bifidobacterium and Lactobacillus are considered the ideal bacteria for the human body because they are commensal bacteria(22,44,52,59). The early presence of Bifidobacterium between one week and three months of age was associated with a lower risk of developing eczema(59-60). Additionally, a decreased number of Bifidobacterium and Lactobacillus seem to be related to the emergence of allergies ${ }^{(42,52,59)}$. Some studies do not report significant differences between the microbiota of asthmatic and healthy individuals; however, low levels of Bifidobacterium are found in the long run among individuals with asthma, compared to recently diagnosed individuals ${ }^{(61)}$.

Another component found in the microbiota of newborns is Bacteroides. Some of them help regulate gut immunity, and a deficiency of these bacteria was identified among infants born via C-section. This situation causes the rupture of tolerogenic response, contributing to inflammation and obesity ${ }^{(37,42)}$. Additionally, these bacteria are involved in the digestion of human milk, and scarcity of these in the neonatal gut may cause digestive problems ${ }^{(26,28)}$.

These claims are explained based on the Old Friends theory. Commensal microorganisms train the immunological system to develop tolerance mechanisms as a strategy for their own survival. Hence, the immune system recognizes and eliminates harmful bacteria but does not react against useful species or the organism itself ${ }^{(60,62)}$. Old Friends bacteria can activate the production of anti-inflammatory cytokines, differentiating themselves from pathogens that promote pro-inflammatory cytokines ${ }^{(52,62)}$,

Regarding the route of birth delivery and neonatal microbiota, the first influences the acquisition and colonization of bacteria in newborns' bodies $^{(22-44,52,63)}$, especially during early childhood, usually stabilizing in the first year of life ${ }^{(35)}$. An infant's immune system is exposed for the first time to microorganisms during vaginal delivery or C-section ${ }^{(12)}$.

Many of an infant's body sites come into contact with the environment's microbiota, and colonization occurs. The studies analyzed the neonatal microbial colonization in various body sites, and the gut was the site most frequently studied using fecal samples ${ }^{(12,21-22,24-26,28,31,33,36-37,40-41,43-44)}$. Others studies analyzed the $\operatorname{skin}^{(12,27,44)}$, and oral and nasal mucosa(12,21,27,30-32,34-35,44). However, it is argued that bacterial communities show a homogeneous distribution pattern in the most diverse body habitats; i.e., regardless of the route of birth, microbial colonization shows little or no differences between body sites ${ }^{(27,42)}$.

Infants born vaginally have a higher concentration of Bacteroides, Bifidobacterium, and Lactobacillus in the first days of life, and a greater microbial variability occurs in the following weeks ${ }^{(22,33,43,47,62)}$. These infants' microbiota is more similar to their mothers' vaginal microbiome ${ }^{(21-22,27,44,64)}$. Note that the main bacterial communities found in mothers' vaginas are Lactobacillus, Bifidobacterium, and Streptococcus( ${ }^{(65-66)}$, though there are controversies in the literature. The vaginal flora composition during pregnancy is relatively less diverse compared to that of non-pregnant women. This is due 
to a decreased number of some members of the vaginal community and enrichment of Lactobacillus target species. Hence, the composition of a pregnant woman's vaginal microbiota is more stable, conferring a protective role against ascending infections ${ }^{(65)}$.

Infants born via C-section present a microbiome similar to the maternal skin and the hospital environment ${ }^{(47,56,62-63)}$, which is also less diverse, mainly composed of Staphylococcus, Streptococcus, and Clostridium. Although, a longitudinal study ${ }^{(29)}$ addressing 43 infants reports a significantly greater bacterial diversity among those born via $\mathrm{C}$-section than those born vaginally. This variety, however, decreased from the first month of life up to two years of age while these children presented less phylogenetic richness compared to children born vaginally(29).

The Staphylococcus, Clostridium, Klebsiella, Enterobacter, and Enterococcus species were more frequently found among infants born via C-section. These bacteria are resistant to various antibiotics and are endemic in the hospital setting ${ }^{(22-23,25-26,35,44)}$. Studies suggest that C-sections cause effects similar to the use of antibiotics, changing the maturation patterns of microbiota in neonates ${ }^{(29)}$.

On the other hand, the effects of elective and emergency C-sections differ ${ }^{(35)}$. Elective C-sections imposed a greater risk of asthma than emergency C-sections( ${ }^{(32)}$. Infants born via emergency C-section undergo the effects of labor and, for this reason, have a bacterial composition similar to that of infants born vaginally $^{(12)}$. Consequently, these children are less likely to develop an immune system problem compared to infants born via elective C-sections.

The microbiota of healthy adults is stable and diversified ${ }^{(67)}$. Aberrant and scarce microbiota are related to various health disorders $(40,42,52,54)$. Additionally, the low diversity of colonizing bacteria is related to a larger number of antibody-secreting cells, causing exaggerated immune responses(67). In this sense, the immune system is believed to have a more beneficial response to the health-disease continuum in the presence of a diverse and stable microbiota.

Despite the systematized search and selection of studies, it is worth mentioning that it is impossible to exhaust the entire literature addressing this topic. Therefore, this study's limitations include the search method, which was restricted to only two databases, the 10-year timeframe, and the fact that only studies written in Portuguese, English, or Spanish (the languages the authors are proficient) were selected.

Notwithstanding its limitations, this study presents evidence of 25 studies, most of which were clinical trials and cohort studies. It clearly shows that the route of birth influences an infant's microbiota, and it is assumed that it may compromise infants' health, influencing the development of allergies, immunological/metabolic diseases, and obesity. Thus, this study contributes to the advancement of scientific knowledge and reinforces the importance of policies and practices intended to discourage C-sections worldwide, but especially in Brazil.

\section{Conclusion}

Microbial colonization during the fetal period, intrapartum, and after birth is crucial in the host-microbial mutualism; the primary function is the maturation and development of newborns' immune systems. The maternal vaginal microbiota provides newborns with a greater variety of colonizing microorganisms, responsible for training and adapting the infants' immune system. Therefore, it is clear that vaginal delivery is ideal, and only in the presence of medical indications should a C-section be endeavored.

Currently, the Brazilian obstetrical service presents high rates of $\mathrm{C}$-sections. The implications of using this route of birth delivery involve increased fetal, neonatal, and maternal morbidity and mortality. In this sense, this study supports the choice of the route of birth delivery and, consequently, favors a decrease in unnecessary $\mathrm{C}$-sections. It is crucial to provide information to pregnant women and/or couples and health workers to make informed and educated decisions.

Research addressing the role of microbiota in human health and its association with the route of birth tends to increase, and further studies are crucial to understanding the complex interaction between one's microbiota and the immune system while the route of birth delivery influences both. Thus, there are gaps concerning the mechanisms involved in the training and maturation of newborns' immune systems and its implications in adulthood.

\section{References}

1. Organização Mundial da Saúde. Declaração da OMS sobre taxas de cesárea. Genebra: WHO; 2015.

2. Domingues RMSM, Dias MAB, Nakamura-Pereira M, Torres JA, d'Orsi E, Pereira APE, et al. Process of decisionmaking regarding the mode of birth in Brazil: from the initial preference of women to the final mode of birth. 2014;30(Supl. 1):S101-S116. doi: 10.1590/0102$311 \times 00105113$

3. Korb D, Goffinet F, Seco A, Chevret S, Deneux-Tharaux C, EPIMOMS Study Group. Risk of severe maternal morbidity associated with cesarean delivery and the 
role of maternal age: a population-based propensity score analysis. CMAJ. 2019 Apr;191(13):E352-E360. doi:10.1503/cmaj.181067

4. Mascarello KC, Horta BL, Silveira MF. Maternal complications and cesarean section without indication: systematic review and meta-analysis. Rev Saúde Pública. 2017;51(105); doi: 10.11606/S15188787.2017051000389

5. Rocha Filho EA, Costa ML, Cecatti JG, Parpinelli MA, Haddad SM, Pacagnella RC, et al. Severe maternal morbidity and near miss due to postpartum hemorrhage in a national multicenter surveillance study. Int J Gynaecol Obstet. 2015 Nov 6;128:131-6. doi: 10.1016/j. ijgo.2014.08.023

6. Cardoso PO, Alberti LR, Petroianu A. Neonatal and maternal morbidity related to the type of delivery. Ciênc Saúde Coletiva. 2010;15(2):427-35. doi: https://doi. org/10.1590/S1413-81232010000200019

7. Monteiro TLVA, Da Silva RC, De Sousa GC, Neiva MJLM. Puerperal infection events in a reference maternity in the city of Caxias, Maranhão. Rev Enferm UFPI. 2016 Apr;5(2):11-5. doi: https://doi.org/10.26694/reufpi. v5i2.5110

8. Alfirevic Z, Milan SJ, Livio S. Caesarean section versus vaginal delivery for preterm birth in singletons. Cochrane Database Syst Rev. 2013 Sep 13;6(9). doi: 10.1002/14651858.CD000078.pub3

9. Sevelsted A, Stokholm J, Bønnelykke K, Bisgaard $\mathrm{H}$. Cesarean Section and Chronic Immune Disorders. Pediatrics.2015 jan;135(1). doi: 10.1542/peds.2014-0596 10. Aguero MC, Ganal-Vonarburg SC, Fuhrer T, Rupp S, Uchimura $\mathrm{Y}, \mathrm{Li} \mathrm{H}$, et al. The maternal microbiota drives early postnatal innate immune development. Science. 2016 Mar 18;351(6279):1296-302. doi: $10.1126 /$ science.aad 2571

11. Arboleya S, Suárez M, Fernández N, Mantecón L, Solís G, Gueimonde M, et al. C-section and the Neonatal Gut Microbiome Acquisition: Consequences for Future Health. Ann Nutr Metab. 2018;73 Suppl 3:17-23. doi: $10.1159 / 000490843$

12. Dominguez-Bello MG, De Jesus-Laboy KM, Shen N, Cox LM, Amir A, Gonzalez A, et al. Partial restoration of the microbiota of cesarean-born infants via vaginal microbial transfer. Nature Med. 2016 Feb 01;(22):250-3. doi: $10.1038 / \mathrm{nm} .4039$

13. Botelho LLR, Cunha CCA, Macedo M. The integrative review method in organizational studies. Gestão Soc. 2011 Dec 02;5(11):121-36. doi: 10.21171/ges.v5i11.1220

14. Souza MT, Silva MD, Carvalho R. Integrative review: what is it? How to do it? Einstein (São Paulo). 2010;1(8):102-6. doi: https://doi.org/10.1590/s167945082010 rw 1134
15. Mendes KDS, Silveira RCDCP, Galvão CM. Integrative literature review: a research method to incorporate evidence in health care and nursing. Texto Contexto Enferm. 2008;17(4):758-64. doi: 10.1590/S010407072008000400018

16. Santos CMC, Pimenta CAM, Nobre MC. The PICO strategy for the research question construction and evidence search. Rev. Latino-Am Enfermagem. 2007 May-Jun;15(3). doi: https://doi.org/10.1590/S010411692007000300023

17. Pereira MG, Galvão TF. Steps on searching and selecting studies for systematic reviews of the literature. Epidemiol Serv Saude. 2014 Apr-Jun;23(2):369-71. doi: 10.5123/S1679-49742014000200019

18. Moher D, Liberati A, Tetzlaff J, Altman DG, The PRISMA Group. Preferred Reporting Items for Systematic Reviews and Meta-Analyses: The PRISMA Statement. PLoS Med. 2009;6(7): e1000097. doi: 10.1371/journal. pmed 1000097

19. Ursi ES. Prevenção de lesões de pele no perioperatório: revisão integrativa da literatura. [Dissertação]. Ribeirão Preto: Escola de Enfermagem; 2005. doi: 10.11606/D.22.2005.tde-18072005-095456 20. Melnyk BM, Fineout-Overholt E. Making the case for evidence-based practice. In: Melnyk BM, Fineout-Overholt $E$, organizers. Evidence-based practice in nursing and healthcare: A guide to best practice. 2nd ed. Philadelphia: Lippincott Williams \& Wilkins; 2005. p. 3-24.

21. Liu CJ, Liang $X$, Niu ZY, Jin Q, Zeng XQ, Wang WX, et al. Is the delivery mode a critical factor for the microbial communities in the meconium? EBioMedicinE. 2019 Nov; 49:354-63. doi: 10.1016/j.ebiom.2019.10.045

22. Reyman $M$, van Houten MA, van Baarle $D$, Bosch AATM, Man WH, Chu MLJN, et al. Impact of delivery modeassociated gut microbiota dynamics on health in the first year of life. Nat Commun. 2019; Nov 1;10(1):4997. doi: 10.1038/s41467-019-13014-7

23. Li H, Wang J, Wu L, Luo J, Liang X, Xiao B, Zhu Y. The impacts of delivery mode on infant's oral microflora. Sci Rep. 2018;Aug 9;8(1):11938. doi: 10.1038/s41598018-30397-7

24. Shi YC, Guo H, Chen J, Sun G, Ren RR, Guo MZ, et al. Initial meconium microbiome in Chinese neonates delivered naturally or by cesarean section. Sci Rep. 2018; Feb 19;8(1):3255. doi: 10.1038/s41598-018-21657-7 25. Wampach L, Heintz-Buschart A, Fritz JV, RamiroGarcia J, Habier J, Herold $M$, et al. Birth mode is associated with earliest strain-conferred gut microbiome functions and immunostimulatory potential. Nat Commun. 2018 Nov 30;9(1):5091. doi: 10.1038/s41467-018-07631-x 26. Brazier L, Elguero E, Koumavor CK, Renaud N, Prugnolle F, Thomas F, et al. Evolution in fecal bacterial/ 
viral composition in infants of two central African countries (Gabon and Republic of the Congo) during their first month of life. PLoS One. 2017 Oct 02;12(10):1-19. doi: 10.1371/ journal.pone.0185569

27. Chu DM, Ma J, Prince AL, Antony KM, Seferovic MD, Aagaard KM. Maturation of the infant microbiome community structure and function across multiple body sites and in relation to mode of delivery. Nature Med. 2017 Jan 23;23:314-26. doi: 10.1038/nm.4272

28. Hill CJ, Lynch DB, Murphy K, Ulaszewska M, Jeffery IB, O'Shea CA, et al. Evolution of gut microbiota composition from birth to 24 weeks in the INFANTMET Cohort. Microbiome. 2017 Jan 17;5(21):1-18. doi: $10.1186 /$ s40168-016-0213-y

29. Bokulich NA, Chung J, Battaglia T, Henderson N, Jay $\mathrm{M}$, Li $\mathrm{H}$, et al. Antibiotics, birth mode, and diet shape microbiome maturation during early life. Science Translational Medicine. 2016 Jun 15;8(343):343-82. doi: 10.1126/scitransImed.aad7121

30. Bosch AATM, Levin E, Van Houten MA, Hasrat R, Kalkman G, Biesbroek G, et al. Development of Upper Respiratory Tract Microbiota in Infancy is Affected by Mode of Delivery. EBioMedicine. 2016 Jul;9:336-45. doi: 10.1016/j.ebiom.2016.05.031

31. Brumbaugh DE, Arruda J, Robbins K, Ir D, Santorico AS, Robertson CE, et al. Mode of Delivery Determines Neonatal Pharyngeal Bacterial Composition and Early Intestinal Colonization. JPGN. 2016 Sep;63(3):320-8. doi: 10.1097/MPG.0000000000001124

32. Kristensen K, Henriksen L. Cesarean section and disease associated with immune function. J Allergy Clin Immunol. 2016 Feb;137(2):587-90. doi: 10.1016/j. jaci.2015.07.040

33. Martin R, Makino H, Yavuz AC, Ben-Amor K, Roelofs M, Ishikawa $E$, et al. Early-Life Events, Including Mode of Delivery and Type of Feeding, Siblings and Gender, Shape the Developing Gut Microbiota. PLoS One. 2016 Jun 30;11(6):1-30. doi: 10.1371/journal.pone.0158498 34. Shilts MH, Rosas-Salazar C, Tovchigrechko A, Larkin EK, Torralba M, Akopov A, et al. Minimally Invasive Sampling Method Identifies Differences in Taxonomic Richness of Nasal Microbiomes in Young Infants Associated with Mode of Delivery. Microbial Ecol. 2016 Jan;71(1):23342. doi: 10.1007/s00248-015-0663-y

35. Stokholm J, Thorsen J, Chawes BL, Schjørring S, Krogfelt KA, Bønnelykke $K$, et al. Cesarean section changes neonatal gut colonization. J Allergy Clin Immunol. 2016 Sep;138(3):881-9. doi: 10.1016/j. jaci.2016.01.028

36. Bäckhed F, Roswall J, Peng Y, Feng Q, Jia H, Kovatcheva-Datchary $P$, et al. Dynamics and Stabilization of the Human Gut Microbiome during the First Year of
Life. Cell Host Microbe. 2015 May 13;17(5):690-703. doi: 10.1016/j.chom.2015.04.004

37. Dogra S, Sakwinska O, Soh SE, Ngom-Bru C, Brück WM, Berger B, et al. Dynamics of infant gut microbiota are influenced by delivery mode and gestational duration and are associated with subsequent adiposity. mBio. 2015 Feb 03;6(1):1-9. doi: 10.1128/mBio.02419-14

38. Dong L, Jialin $Y$, Luquan L, Qing A, Jinxing F, Chao $S$, et al. Bacterial Community Structure Associated With Elective Cesarean Section Versus Vaginal Delivery in Chinese Newborns. JPGN. 2015 Feb;60(2):240-6. doi: 10.1097/MPG.0000000000000606

39. Hesla HM, Stenius F, Jaderlund L, Nelson R, Engstrand $\mathrm{L}$, Alm J, et al. Impact of lifestyle on the gut microbiota of healthy infants and their mothers - the ALADDIN birth cohort. FEMS Microbiol Ecol. 2014 Dec 01;90(1):791-801. doi: 10.1111/1574-6941.12434

40. Jakobsson HE, Abrahamsson TR, Jenmalm MC, Harris K, Quince C, Jernberg C, et al. Decreased gut microbiota diversity, delayed Bacteroidetes colonisation and reduced Th1 responses in infants delivered by caesarean section. Gut. 2014;63(4):559-66. doi: 10.1136/ gutjnl-2012-303249

41. Makino $H$, Kushiro A, Ishikawa E, Kubota H, Gawad A, Sakai T, et al. Mother-to-infant transmission of intestinal bifidobacterial strains has an impact on the early development of vaginally delivered infant's microbiota. PLoS One. 2013 Nov 14;8(11):1-10. doi: 10.1371/journal. pone.0078331

42. Pandey PK, Verma P, Kumar H, Bavdekar A, Patole MS, Shouche YS. Comparative analysis of fecal microflora of healthy full-term Indian infants born with different methods of delivery (vaginal vs cesarean): Acinetobacter sp. prevalence in vaginally born infants. Bioscience J. 2012 Dec;31(1):989-98. doi: 10.1007/s12038-012-9268-5 43. Biasucci G, Rubini M, Riboni S, Morelli L, Bessi E, Retetangos $C$. Mode of delivery affects the bacterial community in the newborn gut. Early Hum Dev. 2010 Jun;86(1):13-5. doi: 10.1016/j.earlhumdev.2010.01.004 44. Dominguez-Bello MG, Costello EK, Contreras M, Magris M, Hidalgo G, Fierer N, et al. Delivery mode shapes the acquisition and structure of the initial microbiota across multiple body habitats in newborns. PNAS. 2010 Jun 29;107(26):11971-5. doi: 10.1073/pnas.1002601107 45. Maynard CL, Elson CO, Hatton RD, Weaver CT. Reciprocal Interactions of the Intestinal Microbiota and Immune System. Nature. 2012 Sep 12;489(7415)231-41. doi: $10.1038 /$ nature 11551

46. Francino MP. Birth Mode-Related Differences in Gut Microbiota Colonization and Immune System Development. Ann Nutr Metab. 2018;73 Suppl 3:12-16. doi: $10.1159 / 000490842$ 
47. Rutayisire E, Huang K, Liu Y, Tao F. The mode of delivery affects the diversity and colonization pattern of the gut microbiota during the first year of infants' life: a systematic review. BMC Gastroenterol. 2016 Jul 30;16(86):1-12. doi: 10.1186/s12876-016-0498-0

48. Belkaid $Y$, Hand $T$. Role of the Microbiota in Immunity and Inflammation. Cell. 2014 Mar 27;157(1):121-41. doi: 10.1016/j.cell.2014.03.011

49. Unger SA, Bogaert D. The respiratory microbiome and respiratory infections. J Infect. 2017 Jun 23;74(1):s84-8. doi: $10.1016 /$ S0163-4453(17)30196-2

50. Jatzlauk G, Bartel S, Heine H, Schloter M, KraussEtschmann S. Influences of environmental bacteria and their metabolites on allergies, asthma, and host microbiota. Allergy. 2017 Jun 10;72(12):1859-67. doi: 10.1111/all.13220

51. Arboleya S, Suárez M, Fernández N, Mantecón L, Solís G, Gueimonde $M$, et al. C-section and the Neonatal Gut Microbiome Acquisition: Consequences for Future Health. Ann Nutr Metab. 2018;73 Suppl 3:17-23. doi: 10.1159/000490843

52. Miniello VL, Colasanto A, Cristofori F, Diaferio L, Ficele L, LiegGI, MS, et al. Gut microbiota biomodulators, when the stork comes by the scalpel. Clin Chim Acta. 2015 Dec 07;451:88-96. doi: 10.1016/j.cca.2015.01.022

53. Cho CE, Norman M. Cesarean section and development of the immune system in the offspring. Am J Obstet Ginaecol. 2013 Apr;208(4):249-54. doi: 10.1016/j. ajog.2012.08.009

54. Kozyrskyj AL, Bahrein S, Azad MB. Early life exposures: impact on asthma and allergic disease. Current opinion in allergy and clinical immunology. 2011 Oct;11(5):400-6. doi: 10.1097/ACI.0b013e328349b166 55. McLoughlin RM, Mills KHG. Influence of gastrointestinal commensal bacteria on the immune responses that mediate allergy and asthma. J Allergy Clin Immunol. 2011 May;127(5):1097-107. doi: 10.1016/j.jaci.2011.02.012 56. Wang M, Monaco MH, Donovan SM. Impact of early gut microbiota on immune and metabolic development and function. Sem Fetal Neonatal Med. 2016 Dec;21(6):3807. doi: $10.1016 /$ j.siny.2016.04.004

57. Kamada N, Chen GY, Inohara N, Nunez G. Control of pathogens and pathobionts by the gut microbiota. Nature Immunol. 2013 Jun 18;14:685-90. doi: 10.1038/ni.2608 58. Oozeer R, Limpt K, Ludwig T, Amor KB, Martin R, Vento RD, et al. Intestinal microbiology in early life: specific prebiotics can have similar functionalities as human-milk oligosaccharides. Am J Clin Nutr. 2013 Jul 03;98(2):561-71. doi: 10.3945/ajcn.112.038893

59. Ismail IH, Boyle RJ, Licciardi PV, Oppedisano F, Lahtinen S, Robins-Browne RM, et al. Early gut colonization by Bifidobacterium breve and $\mathrm{B}$. catenulatum differentially modulates eczema risk in children at high risk of developing allergic disease. Pediatr Allergy Immunol. 2016 Sep 03;27(8). doi: 10.1111/pai.12646

60. Liao Z, Lamb KE, Burgner D, Ranganathan S, Miller JE, Koplin JJ, et al. No obvious impact of caesarean delivery on childhood allergic outcomes: findings from Australian cohorts. Arch Dis Child. 2020 Jul;105(7):664-70. doi: 10.1136/archdischild-2019-317485

61. Hevia A, Milani C, López P, Donado CD, Cuervo A, González S. Allergic Patients with Long-Term Asthma Display Low Levels of Bifidobacterium adolescentis. PLoS One. 2016 Feb 03;11(12). doi: 10.1371/journal. pone.0147809

62. Torrazza RM, Neu J. The developing intestinal microbiome and its relationship to health and disease in the neonate. J Perinatol. 2011 Mar 30;31:s29-s34. doi: 10.1038/jp.2010.172

63. Tamburini S, Shen N, Wu HC, Clemente JC. The microbiome in early life: implications for health outcomes. Nature Med. 2016 Jul 07;22:713-22. doi: 10.1038/ $\mathrm{nm} .4142$

64. Moya-Pérez A, Luczynski P, Renes IB, Wang S, Borre $Y$, Anthony RC, et al. Intervention strategies for cesarean section-induced alterations in the microbiota-gut-brain axis. Nutr Rev. 2017 Apr 01;75(4):225-40. doi: 10.1093/ nutrit/nuw069

65. Romero R, Hassan SS, Gajer P, Tarca AL, Fadrosh DW, Nikita $L$, et al. The composition and stability of the vaginal microbiota of normal pregnant women is different from that of non-pregnant women. Microbiome. 2014 Feb 03;2(10). doi: 10.1186/2049-2618-2-4

66. Aagaard K, Riehle K, Ma J, Segata N, Mistretta T, Coarfa C. A Metagenomic Approach to Characterization of the Vaginal Microbiome Signature in Pregnancy. PLoS ONE. 2012 Jun 13;7(6). doi: 10.1371/journal.pone.0036466 67. Clemente JC, Ursell LK, Parfrey LW, Knight R. The Impact of the Gut Microbiota on Human Health: An Integrative View. Cell Press. 2012 Mar 16;148(6):125870. doi: 10.1016/j.cell.2012.01.035

\section{Authors' contribution:}

Study concept and design: Gabriela Diniz Pinto Coelho, Lilian Fernandes Arial Ayres, Bruno David Henriques, Mara Rúbia Maciel Cardoso Prado. Obtaining data: Gabriela Diniz Pinto Coelho, Daniela Sezilio Barreto, Bruno David Henriques, Camila Mendes Dos Passos. Data analysis and interpretation: Gabriela Diniz Pinto Coelho, Lilian Fernandes Arial Ayres, Daniela Sezilio Barreto, Bruno David Henriques, Mara Rúbia Maciel Cardoso Prado, Camila Mendes Dos Passos. Drafting the manuscript: 
Gabriela Diniz Pinto Coelho, Lilian Fernandes Arial Ayres, Daniela Sezilio Barreto, Mara Rúbia Maciel Cardoso Prado, Camila Mendes Dos Passos. Critical review of the manuscript as to its relevant intellectual content: Lilian Fernandes Arial Ayres, Daniela Sezilio Barreto, Bruno David Henriques, Mara Rúbia Maciel Cardoso Prado, Camila Mendes Dos Passos.

All authors approved the final version of the text. Conflict of interest: the authors have declared that there is no conflict of interest. Creative Commons (CC BY).

This license lets others distribute, remix, tweak, and build upon your work, even commercially, as long as they credit you for the original creation. This is the most accommodating of licenses offered. Recommended for maximum dissemination and use of licensed materials. 